\title{
PENGAWASAN DAN MOTIVASI TERHADAP KINERJA DENGAN KOMITMEN SEBAGAI VARIABEL INTERVENING PADA RSUD MUARADUA OKU SELATAN
}

\author{
Nurhawa ${ }^{1}$ \\ Badia Perizade ${ }^{2}$ \\ Agustina Hanafi ${ }^{3}$ \\ ${ }^{1,2,3}$ Magsiter Ilmu Manajemen, Fakultas Ekonomi, Universitas Sriwijaya \\ email : galuhrich@gmail.com
}

\begin{abstract}
ABSTRAK
Penelitian ini bertujuan untuk menganalisis pengaruh pengawasan dan motivasi terhadap kinerja pegawai dengan komitmen pegawai sebagai variabel intervening. Responden dalam penelitian ini diambil dengan menggunakan metode sensus. Jumlah populasi adalah 97 orang diperoleh dari pengisian kuesioner yang didistribusikan kepada 97 responden. Teknik analisis data yang digunakan adalah Partial Least Square (PLS). Hasil penelitian ini adalah pengawasan tidak berpengaruh terhadap komitmen pegawai, motivasi berpengaruh terhadap komitmen pegawai, pengawasan berpengaruh terhadap kinerja pegawai, motivasi berpengaruh terhadap kinerja pegawai, komitmen pegawai berpengaruh terhadap kinerja pegawai, pengawasan berpengaruh terhadap kinerja pegawai melalui komitmen pegawai sebagai variabel intervening, dan motivasi berpengaruh terhadap kinerja pegawai melalui komitmen pegawai sebagai variabel intervening. Hasil penelitian ini menunjukan bahwa pengawasan dan motivasi berpengaruh terhadap kinerja pegawai dengan komitmen pegawai sebagai variabel intervening. Sebagai saran, pihak manajemen dapat memberikan masukan dan perbaikan kepada pegawai dalam mengerjakan pekerjaan sehingga dapat meningkatkan motivasi karyawan, dengan motivasi yang meningkat dapat meningkatkan komitmen pegawai dan melaksanakan pekerjaan dengan penuh tanggung jawab terhadap Rumah Sakit Daerah Muaradua Kabupaten Ogan Komering Ulu Selatan.

Kata kunci :Pengawasan, Motivasi, Komitmen Pegawai, Kinerja pegawai.
\end{abstract}

\section{ABSTRACT}

The purposeof this study is to analyze the influence of supervision and motivation on employee performance with employee commitment as an intervening variable. Respondents in this study were taken using the census method. The total population was 97 people obtained from filling out questionnaires distributed to 97 respondents. The data analysis technique used was Partial Least Square (PLS). The results of this study showed that supervision did not affect employee commitment, motivation affected employee commitment, supervision affected employee performance, motivation affected employee performance, employee commitment affected employee performance, supervision affected employee performance through employee commitment as a variable intervening, and motivation affected employee performance through employee commitment as an intervening variable.The results of this study indicated that supervision and motivation had influence on employee performance with employee commitment as an intervening variable. It is suggueted to the management to provide input and improvement to employees in doing work to increase employee motivation, with increased motivation can increase employee commitment and carry out work responsibly towards Muaradua General Hospital, South Ogan Komering Ulu Regency.

Keywords :Supervision, Motivation, Employee Commitment, Employee performance. 


\section{PENDAHULUAN}

Sumber daya manusia dalam organisasi maupun perusahaan merupakan tokoh sentral. Agar aktivitas manajemen berjalan dengan baik, maka organisasi dan perusahaan harus memiliki karyawan yang berpengetahuan dan berketerampilan tinggi yang diikuti dengan usaha untuk pengelolaan sumber daya manusia didalam organisasi atau perusahaan tersebut secara konsisten dan berkelanjutan sehingga kinerja karyawan meningkat. Menurut (Robbin SP dan Judge, 2002)Organisasi merupakan kesatuan sosial yang dikoordinasikan secara sadar dengan dengan sebuah batasan yang reaktif dapat diidentifikasikan, bekerja secara terus menerus untuk mencapai tujuan. Semua tindakan yang diambil dalam setiap kegiatan diprakarsai dan ditentukan oleh manusia yang menjadi anggota organisasi.

Dalam mencapai tujuan organisasi sangat bergantung pada baik buruknya kinerja pegawai. Artinya, jika kinerja pegawai pada organisasi itu baik, maka tentunya akan berdampak positif bagi kinerja pegawai, begitupun sebaliknya. Menurut (Suharnomo \& Febriani, 2018) faktor pendukung untuk terciptanya kinerja karyawan yang baik diperlukan komitmen organisasi. Karyawan yang memiliki komitmen yang tinggi pada organisasinya, biasanya akan memberikan seluruh kemampuan dan keterampilannya untuk organisasi tempat ia bekerja agar organisasi tersebut mencapai tujuannya dan berjalan kearah yang lebih baik lagi, dan tentunya juga berpengaruh terhadap meningkatnya kinerja pada karyawan tersebut. Faktor lain yang menciptakan kinerja karyawan di suatu organisasi itu meningkat, yaitu diantaranya pengawasan dan motivasi.

Dalam pelaksanaan kegiatan-kegiatan organisasi yang sedang berjalan diperlukan pengawasan yang dilakukan oleh pimpinan secara maksimal agar pegawai dapat melaksanakan tugas pekerjaanya dengan baik, sehingga dapat mencapai tujuan organisasi dan meningkatnya keberhasilan kinerja pegawai. Pengawasan mengacu pada kegiatan controlling. Menurut (Effendi, 2014) bahwa "Control is to determine what is accomplished, evaluate it, and apply corrective measures, if needed, to insure result in keeping with the plan. Kontrol adalah untuk menentukan apa yang ingin dicapai, mengevaluasi, dan menerapkan langkah-langkah perbaikan, jika diperlukan, untuk memastikan hasil sesuai dengan rencana. Suatu Pengawasan dikatakan penting karena tanpa adanya pengawasan yang baik tentunya akan menghasilkan tujuan yang kurang memuaskan, baik bagi organisasinya itu sendiri maupun bagi para pegawai dengan demikian, pengawasan yang dilakukan oleh pimpinan secara maksimal dan menyeluruh terhadap bawahan dengan memantau dan mengukur seluruh kegiatan yang sedang dijalankan dapat mencegah terjadinya penyimpangan pada setiap kegiatan dan dapat mencapai tujuan yang telah ditetapkan.

Berdasarkan pengamatan yang telah dilakukan peneliti, masih terlihat kurang terealisasinya fungsi pengawasan dengan baik terhadap pegawai RSUD. Kurangnya fungsi pengawasan dikarenakan pimpinan jarang berada ditempat dan sering mengikuti aktifitas diluar RSUD, aktifitas tersebut salah satunya 
merupakan kegiatan dinas luar yaitu mengikuti kegiatan yang ada di pusat. Lemahnya fungsi pengawasan berdampak tidak baik terhadap pegawai yang mengakibatkan tingkat absensi pegawai meningkat.

Hal ini dapat dilihat dari tingkat absensi pegawai pada Tahun 2015-2018 pada Tabel 1. sebagai berikut:

Tabel 1.

Tingkat Absensi Pegawai RSUD Muaradua OKUSelatan Tahun 2016-2018

\begin{tabular}{clccc}
\hline NO & Absensi & \multicolumn{3}{c}{ Persentase } \\
\cline { 3 - 5 } & & $\mathbf{2 0 1 6}$ & $\mathbf{2 0 1 7}$ & $\mathbf{2 0 1 8}$ \\
\hline 1 & Hadir & 77,4 & 76,6 & 80,7 \\
2 & Sakit & 3,7 & 3,2 & 4,3 \\
3 & Izin & 13,04 & 19,4 & 25,9 \\
4 & Terlambat dan Pulang Cepat & 5,02 & 6,20 & 15,2 \\
\hline Sumber & RSUD Muaradua OKUSelatan 2019 & &
\end{tabular}

Berdasarkan Tabel 1. di atas menunjukkan bahwa tingkat absensi ketidakhadiran pegawai terus meningkat per tahunnya, terutama untuk kriteria absensi izin, sakit dan terlambat dan pulang. Hal ini menunjukkan pimpinan kurang maksimal dalam melakukan pengawasan terhadap pegawai nya, ditemukan masih banyak pegawai yang tidak masuk kerja dikarenakan izin, sakit dan terlambat masuk kerja bahkan pulang lebih awal. Berdasarkan Peraturan Pemerintah Republik Indonesia No.53 Tahun 2010 tentang disiplin pegawai Negeri Pasal 3 Poin 11 yang menyatakan bahwa masuk kerja dan mentaati ketentuan jam kerja, ketepatan waktu pada jam kerja berlaku mulai pukul $07.30-$ 16.00 WIB, namun pada RSUD masih ada pegawai terlambat masuk dan ada pegawai pada jam istirahat langsung pulang sebelum jam kerja berakhir. Tingkat absensi pegawai juga dapat dijadikan dasar pengukuran kinerja pegawai, semakin banyak pegawai yang tidak masuk, maka tingkat pengawasan pimpinan masih rendah mengakibatkan kinerja pegawai ikut rendah.

Berdasarkan informasi yang diperoleh dari kepala bagian kepegawaian RSUD bahwa umumnya masalah-masalah yang terlihat di organisasi adalah kurang optimal nya kinerja pegawai. Dalam hal ini pihak manajemen RSUD melakukan upaya peningkatan kualitas kinerja pegawai, dengan memberi motivasi, dengan harapan bahwa motivasi tersebut akan menjadikan karyawan semakin memperbaiki kinerja secara berkelanjutan.

Salah satu bentuk motivasi yang diberikan RSUD adalah berupa pemberian insentif, insentif merupakan bentuk dorongan yang baik dalam melakukan pekerjaan dan meningkatkan motivasi kerja pegawai. Insentif biasanya diberikan setiap bulannya kepada pegawai sesuai dengan tanggung jawab pegawai dalam menyelesaikan pekerjaan. Namun dari bentuk motivasi berupa insentif yang diberikan, tidak serta meningkatkakan motivasi kerja yang lebih dari pegawai maka dari itu RSUD memberikan motivasi non materi misalnya pengakuan dan mendapatkan pelatihan.

Berdasarkan informasi yang diperoleh dari kepala bagian kepegawaian RSUD bahwa pegawai RSUD belum memiliki komitmen pegawai yang tinggi. 
Hal ini terlihat dari data turnover pegawai bahwa terjadi keluar - masuknya pegawai. Berikut data turnover pegawai RSUD OKUSelatan Tahun 2015-2018. Dapat dilihat pada Tabel 2.sebagai berikut :

Tabel 2.

Data Turnover RSUD OKUSelatan

\begin{tabular}{ccccc}
\hline Tahun & $\begin{array}{c}\text { Jumlah Pegawai Akhir } \\
\text { Tahun (orang) }\end{array}$ & Masa Kerja & $\begin{array}{c}\text { Jumlah Pegawai } \\
\text { Keluar (Orang) }\end{array}$ & Persentase \\
\hline 2015 & 94 & $<1$ Tahun & 5 & 5,3 \\
2016 & 108 & $<2$ Tahun & 17 & 15,7 \\
2017 & 115 & $<2$ Tahun & 15 & 13,6 \\
2018 & 135 & - & - & - \\
\hline Sumber :Kepala Bagian SDM RSUD OKUSelatan, 2019 & &
\end{tabular}

Menurut (Gillis, D, 1994)keluarnya karyawan dari rumah sakit dikatakan normal berkisar antara 5 $-10 \%$ per tahun, dikatakan tinggi apabila lebih dari $10 \%$.Berdasarkan masa kerja terjadi pada pegawai yang masih dalam masa kontrak dengan masa kerja $<1$ tahun dan $<2$ tahun. Persentase turnover tertinggi yaitu pada tahun 2016 dengan masa kerja $<2$ tahun sebanyak 17 orang dengan persentase yaitu sebesar 15,7\%. Hal ini juga terjadi pada tahun 2017 dengan masa kerja $<2$ tahun, meskipun pada tahun ini turnover dirumah sakit tersebut mengalami penurunan jumlah yaitu, 15 orang dengan persentase sebesar 13,6\%. Turnover memberikan dampak negatif bagi rumah sakit. Turnover tersebut menyebabkan kerugian, dilihat dari biaya pelatihan yang sudah diinvestasikan pada pegawai lama sampai biaya yang akan dikeluarkan untuk rekrutmen pegawai baru. Menurut kepala bagian kepegawaian Perubahan jumlah pegawai yang terjadi pada setiap tahunnya mengakibatkan terhambatnya pekerjaan yang harus diselesaikan para pegawai dimana harus dilakukannya perubahan penempatan atau posisi pegawai.

Kepala bagian kepegawaian RSUD menyampaikan bahwa sering ditemukan sebagian pegawai memiliki sikap dan prilaku yang tidak memiliki komitmen yang tinggi yaitu pegawai medis yang sering datang terlambat dan tidak ramah pada pasien atau bahkan keluarga pasien. Kemudian pegawai medis cenderung belum mampu dalam menyelesaikan tugas yang diberikan oleh atasan dengan baik dan tepat waktu. Hal tersebut disebabkan karena kurang nya interaksi antara atasan dan bawahan, seperti pemberian bimbingan, dorongan motivasi kepada seluruh anggotanya untuk mencapai tujuan. Selain itu pegawai medis mengeluh mengenai gaji yang mereka terima dikarenakan jumlah yang diterima tidak besar tetapi masih sering terjadinya penunggakan pembayaran gaji, sehingga pada akhirnya menyebabkan kinerja dan komitmen pegawai menjadi rendah.Kepala bagian kepegawaian membenarkan permasalahan tersebut mengakibatkan kinerja pegawai menurun.

Berdasarkan informasi yang diperoleh dari kepala bagian kepegawaian permasalahan tersebut mengakibatkan kinerja pegawai menurun. Menurut (Mathis. L. R. Dan Jackson. H. j, 2001)faktor yang mempengaruhi kinerja individu, yaitu : kemampuan mereka, motivasi, dukungan yang diterima, keberadaan pekerja yang mereka lakukan dan hubungan mereka dengan 
organisasi. Pencapaian kinerja RSUD Muaradua OKU Selatan dapat dilihat pada tabel berikut ini :

Tabel 3.

Target dan Realisasi Jumlah Pasien Tahun 2016-2018

\begin{tabular}{lllll}
\hline No & Tahun & Rawat Jalan & Rawat Inap & Jumlah \\
\hline 1 & 2016 & 34.602 & 1.713 & 36.315 \\
2 & 2017 & 31.702 & 1.912 & 33.614 \\
3 & 2018 & 29.802 & 1.801 & 31.603 \\
\hline
\end{tabular}

Sumber :Rekam Medis RSUD Muaradua OKUSelatan, 2019

Dilihat dari Tabel 3. di atas menunjukan penurunan data pasien pada RSUD Muaradua. Penurunan pasien ini sebagaimana akibat dari kurang optimal nya kinerja pegawai yang berakibat rendahnya kinerja pegawai. Hal ini sesuai dengaan pendapat yang dikemukan oleh (Mangkunegara A. A., 2009)mengemukakan bahwa kinerja adalah hasil kerja kuantitas dan kualitas yang dicapai oleh pegawai dalam melaksanakan tugasnya sesuai dengan tanggung jawab yang diberikan kepadanya.

Pengawasan merupakan fungsi manajemen yang paling esensial, sebaik apapun pekerjaan yang dilaksanakan tanpa adanya pengawasan tidak dapat dikatakan berhasil. Pengawasan yang berhubungan dengan tindakan atau usaha penyelamatan jalannya perusahaan ke arah tujuan yang diinginkan yakni tujuan yang telah direncanakan (Effendi, 2014).

Dalam pengawasan langsung dapat dilakukan dengan peninjauan pribadi yaitu inseksi dengan jalan meninjau secara pribadi sehingga dapat dilihat sendiri pelaksanaan pekerjaan. Pengawasan langsung dapat berupa: inspeksi langsung, pengamatan langsung ditempat, dan membuat laporan di tempat.

Langkah kerja pengawasan atasan langsung menurut Khusnuridho (online) adalah sebagai berikut memeriksa apakah atasan langsung bendaharawan telah melakukan pemeriksaan kas terhadap bendarahawan sedikitnya tiga bulan sekali.Meneliti apakah pejabat yang bertanggung jawab terhadap pengelolaan perlengkapan telah melakukan pemeriksaan penyimpanan barang inventaris yang dikelolanya, baik secara langsung melihat fisik barangnya maupun melalui pembukuannya.

Motivasi merupakan dorongan untuk bertindak terhadap serangkaian proses perilaku manusia dengan mempertimbangkan arah, intensitas, dan ketekunan pada pecapaian tujuan (Effendi, 2014). Motivasi merupakan proses psikologis yang membangkitkan (arousal), mengarahkan (direction), dan ketekunan (persistence) dalam melakukan tindakan secara sukarela yang diarahkan pada pencapaian tujuan (Kreitner dan Knicki, 2010).

(Luthans, 2009) memberikan gagasan bahwa komitmen adalah sikap yang memiliki definisi dan pengukuran yang luas. Komitmen didefinisikan sebagai 1) keinginan kuat untuk tetap menjadi anggota organisasi tertentu, 2) keinginan untuk mencoba menjadi apa yang diinginkan standar perusahaan, 3) keinginan kuat dan penerimaan terhadap nilai dan tujuan perusahaan. perusahaan. Komitmen karyawan sebagai kekuatan relatif dalam mengidentifikasi keterlibatannya ke dalam bagian-bagian organisasi (P, Paramita, \& Wulan, 2016). Teori lain 
menyatakan bahwa komitmen karyawan adalah semacam identifikasi, loyalitas, dan keterlibatan yang diungkapkan oleh karyawan ke organisasi (Gibson et al., 2007). Menurut (Mathew, 2002), pendekatan untuk menjelaskan komitmen karyawan dalam suatu perusahaan dikelompokkan menjadi 4 pendekatan, yaitu: 1) pendekatan sikap, 2) pendekatan multidimensi, 3) pendekatan normatif, dan 4) pendekatan perilaku. (Allen et al., 2001)menjelaskan bahwa ada 3 komponen yang mempengaruhi komitmen karyawan dalam organisasi, di mana karyawan memilih untuk tetap atau meninggalkan organisasi berdasarkan norma yang mereka miliki. Ketiga komponen tersebut adalah: komitmen afektif, komitmen berkelanjutan, dan komitmen normatif.

Kinerja merupakan sebuah hasil dari usaha yang dilakukan oleh seseorang atau organisasi pada suatu aktivitas yang sesuai dengan yang ditetapkan. Menurut (Wilson, 2012) kinerja (performance) adalah hasil pekerjaan yang dicapai seseorang berdasarkan persyaratan-persyaratan pekerjaan (job requirement). Suatu pekerjaan mempunyai persyaratan tertentu untuk dapat dilakukan dalam mencapai tujuan yang disebut juga sebagai standar pekerjaan (job standard).

\section{KERANGKA BERPIKIR}

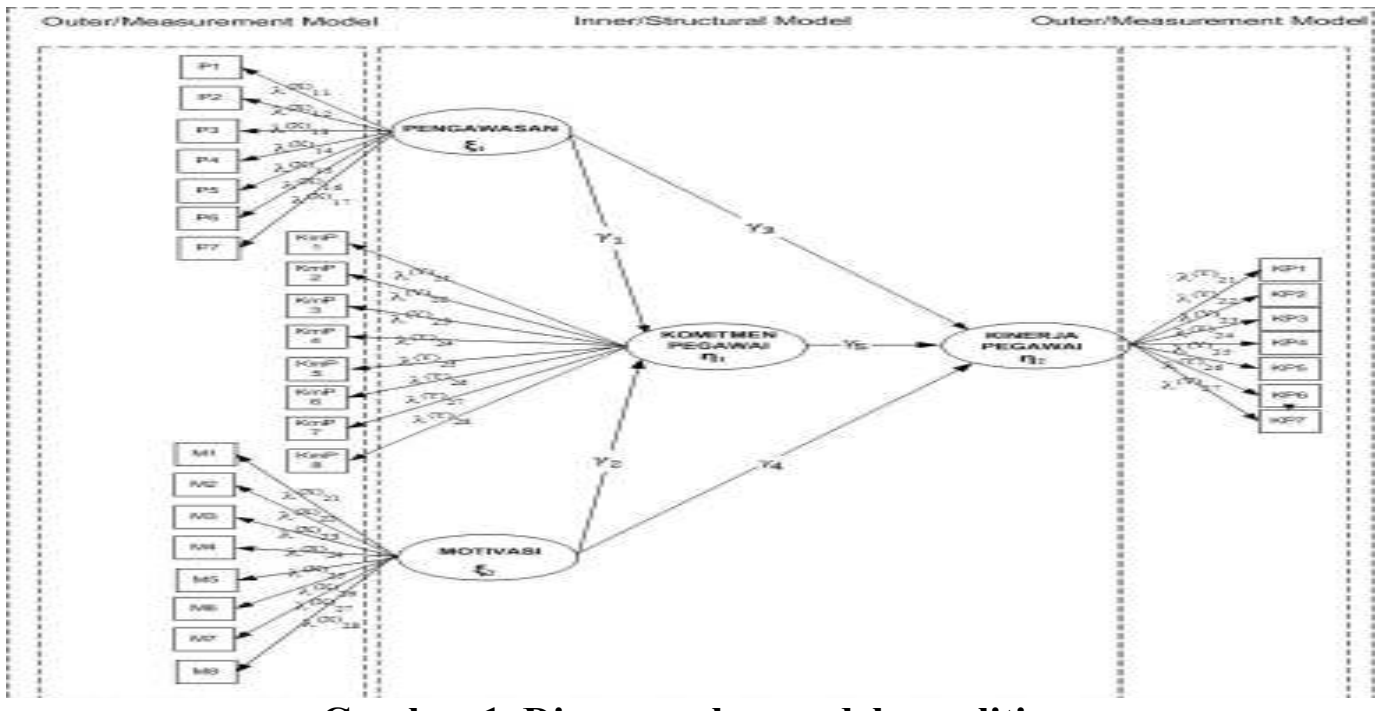

Gambar 1. Diagram alur model penelitian

Berdasarkan pada pengembangan model kerangka pikir diatas, adapun hipotesis pada penelitian ini adalah:

$\mathrm{H}_{1} \quad$ : Pengawasan berpengaruh signifikan terhadap komitmen pegawai

$\mathrm{H}_{2} \quad$ : Motivasi berpengaruh signifikan terhadap komitmen pegawai

$\mathrm{H}_{3} \quad$ : Pengawasan berpengaruh signifikan terhadap kinerja pegawai

$\mathrm{H}_{4}$ : Motivasi berpengaruh signifikan terhadap kinerja pegawai

$\mathrm{H}_{5} \quad$ : Komitmen pegawai berpengaruh signifikan terhadap kinerja pegawai

$\mathrm{H}_{6}$ : Pengawasan berpengaruh signifikan terhadap kinerja pegawai melalui komitmen pegawai

$\mathrm{H}_{7} \quad$ : Motivasi berpengaruh signifikan terhadap kinerja pegawai melalui komitmen pegawai 


\section{METODE PENELITIAN}

Populasi dalam penelitian ini adalah pegawai yang bekerja dilingkungan Rumah Sakit Umum Muaradua. Populasi berjumlah 97 Orang. Sampel dalam penelitian ini di ambil dengan menggunakan metode sensus. Menurut (Harsan, 2011) "jika peneliti menggunakan seluruh elemen populasi menjadi data penelitian maka disebut sensus, sensus digunakan jika elemen populasi bersifat relatif sedikit dan bersifat heteregon". Data yang diperoleh tersebut merupakan hasil pengolahan sensus disebut sebagai data yang sebenarnya (true value) atau sering juga disebut parameter. Dalam penelitian ini sampel yang dipilih yaitu Populasi dalam penelitian ini sebanyak 97 orang yang terdiri dari:

Tabel 4.

Jumlah TKS Berdasarkan Tupoksi Tahun 2018

\begin{tabular}{|c|c|c|}
\hline NO. & Pendidkan & Jumlah per Orang \\
\hline 1. & Perawat IRNA Bedah & 8 \\
\hline 2. & Perawat IRNA Penyakit Dalam & 10 \\
\hline 3. & Perawat IRNA Anak & 6 \\
\hline 4. & Bidan IRNA Anak & 4 \\
\hline 5. & Bidan IRNA Obygn & 8 \\
\hline 6. & Perawat UGD & 6 \\
\hline 7 & Bidan UGD & 4 \\
\hline 8. & Perawat ICU & 1 \\
\hline 9 & Perawat Poli & 4 \\
\hline 10. & Staf Kepegawaian & 23 \\
\hline 11. & Staf Laboratorium & 12 \\
\hline \multirow[t]{2}{*}{12} & $\mathrm{CS}$ & 11 \\
\hline & Jumlah & 97 \\
\hline
\end{tabular}

Sumber: Tata Kelola Administrasi RSUD Daerah Muaradua OKU Selatan, 2019

Data yang digunakan dalam peneitian terdiri atas dua jenis, yaitu data kuantitatif dan data kualitatif (Nawawi, 2005). Data tersebut adalah data kuantitatif dan data Kualitatif. Data Kuantitatif adalah jenis data yang dinyatakan dalam bentuk angka atau jumlah dengan satuan ukur, yang dapat dihitung secara sistematis. Dalam penelitian ini yang termasuk adalah skor jawaban responden dan data kualitatif adalah jenis data yang tidak dalam bentuk angka.

Sumber data yang dipakai dalam penelitian ini adalah :

Data primer. Menurut (Siregar, 2014) Data primer adalah data yang dikumpulkan sendiri oleh peneliti langsung dari sumber pertama atau tempet objek penelitiaan dilakukan. Data primer pada penelitian ini diperoleh melalui kuisioner.

Data Sekunder. Menurut (Sugiyono, 2015) data sekunder adalah data yang telah tersedia dalam berbagai bentuk sumber yang tidak langsung memberikan data kepada pengumpul data, misalnya lewat orang lain, atau lewat dokumen. Data sekunder umumnya berupa bukti, catatan atau laporan historis yang telah tersusun dalam arsip yang dipublikasikan dan yang tidak dipublikasikan. Data sekunder dalam penelitian ini meliputi : Data pegawai, buku-buku referensi, jurnal-jurnal, serta informasi lain yang berhubungan dengan penelitian. 
Dalam penelitian ini teknik yang digunakan untuk mengumpulkan data ialah menggunakan kuesioner. Menurut (Suharnami, 2013) berpendapat bahwa kuesioner adalah sejumlah pertanyaan tertulis yang digunakan untuk memperoleh informasi dari responden dalam arti laporan tentang pribadinya, atau hal-hal yang ia ketahui. Data yang dikumpulkan bersumber dari data hasil kuesioner pegawai RSUD Muaradua OKUSelatan. Jawaban yang disediakan dalam setiap pernyataan atau pertanyaan menggunkan skala likert.

Metode analilis data dalam penelitian ini menggunakan Structural Equation Model (SEM) dalam model dan pengujian hipotesis. Data kuantitatif yang diperoleh melalui kuesioner yang dibagikan kepada responden dianalisis menggunakan Analisa Structural Equation Modeling (SEM) dengan menggunakan software Partial Least Square (PLS).

\section{HASIL DAN PEMBAHASAN}

Rumah Sakit Umum Daerah Muaradua Kabupaten Ogan Komering Ulu Selatan, Beralamatkan Jalan. Raya Ranau Kec. Buay Rawan Kabupaten Ogan Komering Ulu Selatan. Kode Pos 32211. Kode Registrasi Rumah Sakit : 16.08.15. Kepemilikan Kabupaten Ogan Komering Ulu Selatan Dengan Luas Tanah Lebih Kurang Seluas 3 (Tiga) Hektar. Rsud Muaradua Dibangun Pada Tahun 2007, dioperasikan Pada Tahun 2009. Rumah Sakit Muaradua Memiliki Visi Menjadi Rumah Sakit Dengan Pelayanan Berkualitas, Kebanggaan Masyarakat OKU Selatan, Dan Memunyai Misi Memberikan Pelayanan Kesehatan Yang Berkualitas, Meningkatkan Profesionalisme Sumber Daya Masyarakar (SDM). Meningkatkan Sarana Dan Prasarana Kesehatan Yang Modern.

Responden dalam penelitian ini adalah PegawaiRumah Sakit Umum Muaradua yang berjumlah 97 Orang. Dari penyebaran kuesioner yang dilakukan, Secara umum adapun deskriptif responden dalam penelitian ini dikategorikan dan dijelaskan sebagai berikut:

Tabel 5.

Jumlah Responden Berdasarkan Jenis Kelamin

\begin{tabular}{cccc}
\hline No & $\begin{array}{c}\text { Jenis } \\
\text { Kelamin }\end{array}$ & Jumlah (Orang) & Persentase (\%) \\
\hline 1. & Laki-Laki & 29 & 29.90 \\
2. & Perempuan & 68 & 70.10 \\
& Total & $\mathbf{9 7}$ & $\mathbf{1 0 0}$ \\
No & Tingkat Usia (Tahun) & & 5.15 \\
1. & $<25$ Tahun & 5 & 82.47 \\
2. & $25-35$ Tahun & 80 & 7.22 \\
3. & $36-45$ Tahun & 7 & 4.12 \\
4. & $46-55$ Tahun & 4 & 1.04 \\
5. & $>55$ Tahun & 1 & \\
\hline Bersambung... & &
\end{tabular}


E-Jurnal Manajemen, Vol. 8, No. 12, 2019 : 7239-7259

Lanjutan Tabel 5.

\begin{tabular}{|c|c|c|c|}
\hline No & $\begin{array}{c}\text { Jenis } \\
\text { Kelamin }\end{array}$ & Jumlah (Orang) & Persentase (\%) \\
\hline & Total & 97 & 100 \\
\hline No & & & \\
\hline 1. & SMA & 23 & 23.71 \\
\hline 2. & Diploma & 52 & 53.61 \\
\hline 3. & S1 & 22 & 22.68 \\
\hline & Total & 97 & 100 \\
\hline \multicolumn{4}{|c|}{ Masa Kerja } \\
\hline \multicolumn{2}{|c|}{$<5$ Tahun } & 61 & 62.89 \\
\hline \multicolumn{2}{|c|}{$5-10$ Tahun } & 36 & 37.11 \\
\hline \multicolumn{2}{|c|}{ Total } & 97 & 100 \\
\hline
\end{tabular}

Tabel 6.

Rangkuman Persepsi Responden terhadap Variabel Pengawasan

\begin{tabular}{|c|c|c|c|c|c|c|c|c|c|c|c|}
\hline \multirow{2}{*}{\multicolumn{2}{|c|}{ ITEM PERTANYAAN }} & \multicolumn{2}{|r|}{ STS } & \multicolumn{2}{|c|}{ TS } & \multicolumn{2}{|r|}{$\mathbf{N}$} & \multicolumn{2}{|c|}{$\mathbf{S}$} & \multicolumn{2}{|c|}{ SS } \\
\hline & & 1 & $\%$ & 2 & $\%$ & 3 & $\%$ & 4 & $\%$ & 5 & $\%$ \\
\hline P1 & $\begin{array}{l}\text { Pimpinan sering } \\
\text { melakukan } \\
\text { pengawasan langsung } \\
\text { kepada pegawai. }\end{array}$ & 0 & 0,00 & 2 & 2,06 & 4 & 4,12 & 54 & 55,67 & 37 & 38,14 \\
\hline P2 & $\begin{array}{lr}\text { Pimpinan sering } \\
\text { melakukan observasi } \\
\text { langsung di tempat } \\
\text { sebelum kegiatan } \\
\text { dilaksanakan. }\end{array}$ & 0 & 0,00 & 6 & 6,19 & 19 & 19,59 & 48 & 49,48 & 24 & 24,74 \\
\hline P3 & $\begin{array}{l}\text { Pimpinan sering } \\
\text { meninjau ruang kerja } \\
\text { pegawai. }\end{array}$ & 0 & 0,00 & 8 & 8,25 & 35 & 36,08 & 37 & 38,14 & 17 & 17,53 \\
\hline P4 & $\begin{array}{l}\text { Pimpinan melakukan } \\
\text { pengawasan dengan } \\
\text { mengoreksi jika } \\
\text { terdapat kesalahan } \\
\text { dalam bekerja. }\end{array}$ & 0 & 0,00 & 8 & 8,25 & 36 & 37,11 & 32 & 32,99 & 21 & 21,65 \\
\hline P5 & $\begin{array}{l}\text { Pimpinan memberikan } \\
\text { sanksi tegas atas } \\
\text { pelanggaran yang } \\
\text { dilakukan pegawai. }\end{array}$ & 2 & 2,06 & 6 & 6,19 & 18 & 18,56 & 47 & 48,45 & 24 & 24,74 \\
\hline
\end{tabular}

Bersambung... 
Lanjutan Tabel 6.

\begin{tabular}{|c|c|c|c|c|c|c|c|c|c|c|c|c|}
\hline \multirow{2}{*}{\multicolumn{3}{|c|}{ ITEM PERTANYAAN }} & \multicolumn{2}{|r|}{ STS } & \multicolumn{2}{|c|}{ TS } & \multicolumn{2}{|r|}{$\mathbf{N}$} & \multicolumn{2}{|c|}{$\mathbf{S}$} & \multicolumn{2}{|c|}{ SS } \\
\hline & & & 1 & $\%$ & 2 & $\%$ & 3 & $\%$ & 4 & $\%$ & 5 & $\%$ \\
\hline P6 & $\begin{array}{l}\text { Pimpinan } \\
\text { pegawai } \\
\text { membuat } \\
\text { pekerjaan } \\
\text { tertulis dan }\end{array}$ & $\begin{array}{r}\text { meminta } \\
\text { untuk } \\
\text { laporan } \\
\text { secara } \\
\text { isan. }\end{array}$ & 0 & 0,00 & 18 & 18,56 & 22 & 22,68 & 36 & 37,11 & 21 & 21,65 \\
\hline P7 & $\begin{array}{l}\text { Pimpinan } \\
\text { memberikan } \\
\text { tanggapan } \\
\text { hasil } \\
\text { pekerjaan. }\end{array}$ & $\begin{array}{r}\text { terhadap } \\
\text { laporan }\end{array}$ & 0 & 0,00 & 4 & 4,12 & 13 & 13,40 & 56 & 57,73 & & \\
\hline & Rata-rata & & & 0,29 & & ,66 & & 1,65 & & 5,66 & & \\
\hline
\end{tabular}

Sumber: Data Primer Diolah, 2019

Berdasarkan Tabel 6. Dari variabel Pengawasan mayoritas responden menjawab pertanyaan Setuju sebesar $45,66 \%$ sedangkan yang menjawab tidak setuju dari pertanyaan kuesioner pada variabel pengawasan hanya sebesar $0,29 \%$. (Harahap, 2011)mengemukakan bahwa Pengawasan merupakan upaya memeriksa aktifitas yang dilakukan, apakah semua terjadi sesuai dengan rencana yang telah ditetapkan, apakah sesuai dengan perintah yang dikeluarkan, dan apakah sesuai dengan prinsip yang dianut. Pengawasan sama dengan pengendalian sebagai proses memantau kegiatan-kegiatan untuk memastikan bahwa kegiatan-kegiatan itu diselesaikan sebagaimana telah direncanakan dan proses mengoreksi setiap penyimpangan yang berarti (Effendi, 2014).

Tabel 7.

Rangkuman Persepsi Responden terhadap VariabelMotivasi

\begin{tabular}{lcccccccccc}
\hline & STS & TS & N & & S & \multicolumn{2}{c}{ SS } \\
ITEM PERTANYAAN & & & & & & & & & & \\
\cline { 2 - 10 }
\end{tabular}

\begin{tabular}{llllllllllll}
\hline M1 & $\begin{array}{l}\text { Pegawai selalu dilibatkan } \\
\text { dalam pertemuan atau } \\
\text { rapat dalam mengambil } \\
\text { keputusan organisasi }\end{array}$ & 0,00 & 0 & 0,00 & 16 & 16,49 & 60 & 61,86 & 21 & 21,65 \\
M2 & $\begin{array}{l}\text { Adanya dorongan untuk } \\
\text { bekerja dengan baik. }\end{array}$ & 0 & 0,00 & 2 & 2,06 & 14 & 14,43 & 67 & 69,07 & 14 & 14,43 \\
& & & & & & & & & & & \\
\end{tabular}

Bersambung... 
Lanjutan Tabel 7.

\begin{tabular}{|c|c|c|c|c|c|c|c|c|c|c|c|}
\hline \multirow{2}{*}{\multicolumn{2}{|c|}{ ITEM PERTANYAAN }} & \multicolumn{2}{|c|}{ STS } & \multicolumn{2}{|c|}{ TS } & \multicolumn{2}{|r|}{$\mathbf{N}$} & \multicolumn{2}{|r|}{$\mathbf{S}$} & \multicolumn{2}{|c|}{ SS } \\
\hline & & 1 & $\%$ & 2 & $\%$ & 3 & $\%$ & 4 & $\%$ & 5 & $\%$ \\
\hline M3 & $\begin{array}{l}\text { Pegawai merasa tenang } \\
\text { dalam bekerja karena } \\
\text { tersedianya jaminan } \\
\text { kesehatan dari tempat } \\
\text { bekerja. }\end{array}$ & 0 & 0,00 & 0 & 0,00 & 4 & 4,12 & 63 & 64,95 & 30 & 30,93 \\
\hline M4 & $\begin{array}{l}\text { Pegawai merasa bahwa } \\
\text { kebutuhan secara wajar } \\
\text { sudah terpenuhi. }\end{array}$ & 0 & 0,00 & 2 & 2,06 & 21 & 21,65 & 54 & 55,67 & 20 & 20,62 \\
\hline M5 & $\begin{array}{l}\text { Pegawai bekerja keras } \\
\text { agar cepat naik jabatan. }\end{array}$ & 0 & 0,00 & 2 & 2,06 & 17 & 17,53 & 64 & 65,98 & 14 & 14,43 \\
\hline M6 & $\begin{array}{l}\text { Pegawai merasa puas atas } \\
\text { insentif yang diberikan. }\end{array}$ & 0 & 0,00 & 6 & 6,19 & 26 & 26,80 & 53 & 54,64 & 12 & 12,37 \\
\hline M7 & $\begin{array}{l}\text { Diperlukan pemberian } \\
\text { insentif secara adil sesuai } \\
\text { dengan prestasi kerja } \\
\text { pegawai. }\end{array}$ & 0 & 0,00 & 7 & 7,22 & 26 & 26,80 & 50 & 51,55 & 14 & 14,43 \\
\hline M8 & $\begin{array}{l}\text { Pemberian insentif dapat } \\
\text { memotivasi pegawai } \\
\text { dalam melaksanakan } \\
\text { pekerjaan untuk lebih } \\
\text { baik. }\end{array}$ & 0 & 0,00 & 9 & 9,28 & 37 & 38,14 & 34 & 35,05 & 17 & 17,53 \\
\hline
\end{tabular}

\begin{tabular}{llllll}
\hline Rata-rata & 0,00 & 3,61 & 20,75 & 57,35 & 18,30
\end{tabular}

Sumber: Data Primer Diolah, 2019

Berdasarkan Tabel 7. Dari variabel Motivasi mayoritas responden menjawab pertanyaan Setuju sebesar $57,35 \%$ sedangkan yang menjawab tidak setuju dari pertanyaan kuesioner pada variabel Motivasi hanya sebesar 3,61\%. Menurut Thacker dalam(Husnawati, 2006)yang menunjukkanbahwa suksesnya implementasi program motivasi kerja secara keseluruhanberdampak positif terhadap komitmen pegawai.Sementara penelitian (Zin, 2004) dan (Husnawati, 2006) menunjukkan bahwa untuk meningkatkan komitmen pegawai perusahaan harus mengembangkan suatu motivasi kerja dengan memberikan kesempatan bagi pegawai untuk mengembangkan diri melalui program pelatihan dan berpartisipasi dalam setiap pengambilan keputusan yang berhubungan dengan pekerjaan mereka.Motivasi adalah keinginan untuk berusaha sekuat tenaga untuk mencapai tujuan organisasi yang dikondisikan atau ditentukan oleh kemanapun usaha untuk memenuhi suatu kebutuhan individu (Robbins and Stephen D, 2008). 
Tabel 8.

\section{Rangkuman Persepsi Responden terhadap Variabel Komitmen Pegawai}

\begin{tabular}{|c|c|c|c|c|c|c|c|c|c|c|c|}
\hline \multirow{2}{*}{\multicolumn{2}{|c|}{ ITEM PERTANYAAN }} & \multicolumn{2}{|c|}{ STS } & \multicolumn{2}{|c|}{ TS } & \multicolumn{2}{|c|}{$\mathbf{N}$} & \multicolumn{2}{|c|}{$\mathbf{S}$} & \multicolumn{2}{|r|}{ SS } \\
\hline & & 1 & $\%$ & 2 & $\%$ & 3 & $\%$ & 4 & $\%$ & 5 & $\%$ \\
\hline $\mathrm{KmP1}$ & $\begin{array}{l}\text { Pegawai bangga } \\
\text { menceritakan kepada } \\
\text { orang lain, bahwa } \\
\text { organisasi tempat nya } \\
\text { bekerja adalah } \\
\text { organisasi yang bagus. }\end{array}$ & 0 & 0,00 & 0 & 0,00 & 4 & 4,12 & 55 & 56,70 & 38 & 39,18 \\
\hline $\mathrm{KmP} 2$ & $\begin{array}{l}\text { Pegawai merasa bahwa } \\
\text { inilah organisasi yang } \\
\text { baik untuk tempat } \\
\text { bekerja. }\end{array}$ & 0 & 0,00 & 4 & 4,12 & 12 & 12,37 & 56 & 57,73 & 25 & 25,77 \\
\hline $\mathrm{KmP3}$ & $\begin{array}{l}\text { Perusahaan tempat } \\
\text { pegawai bekerja } \\
\text { membuat pegawai } \\
\text { termotivasi untuk } \\
\text { berprestasi lebih baik } \\
\text { lagi. }\end{array}$ & 0 & 0,00 & 0 & 0,00 & 8 & 8,25 & 59 & 60,82 & 30 & 30,93 \\
\hline $\mathrm{KmP} 4$ & $\begin{array}{l}\text { Organisasi tempat } \\
\text { pegawai bekerja } \\
\text { menginspirasi pegawai } \\
\text { untuk selalu bekerja } \\
\text { keras dalam } \\
\text { memajukan organisasi. }\end{array}$ & 0 & 0,00 & 2 & 2,06 & 18 & 18,56 & 55 & 56,70 & 22 & 22,68 \\
\hline $\mathrm{KmP5}$ & $\begin{array}{l}\text { Pegawai setuju dengan } \\
\text { nilai-nilai yang dianut } \\
\text { oleh organisasi. }\end{array}$ & 0 & 0,00 & 2 & 2,06 & 2 & 2,06 & 65 & 67,01 & 28 & 28,87 \\
\hline $\mathrm{KmP6}$ & $\begin{array}{l}\text { Nilai-nilai yang } \\
\text { pegawai anut sama } \\
\text { dengan nilai-nilai yang } \\
\text { dianut oleh organisasi. }\end{array}$ & 0 & 0,00 & 2 & 2,06 & 6 & 6,19 & 63 & 64,95 & 26 & 26,80 \\
\hline $\mathrm{KmP7}$ & $\begin{array}{l}\text { Pegawai bekerja keras } \\
\text { untuk memajukan } \\
\text { organisasi }\end{array}$ & 0 & 0,00 & 0 & 0,00 & 10 & 10,31 & 66 & 68,04 & 21 & 21,65 \\
\hline
\end{tabular}

Bersambung... 
Lanjutan Tabel 8.

\begin{tabular}{|c|c|c|c|c|c|c|c|c|c|c|c|}
\hline \multirow{2}{*}{\multicolumn{2}{|c|}{ ITEM PERTANYAAN }} & \multicolumn{2}{|c|}{ STS } & \multicolumn{2}{|c|}{ TS } & \multicolumn{2}{|r|}{$\mathbf{N}$} & \multicolumn{2}{|r|}{$\mathbf{S}$} & \multicolumn{2}{|r|}{ SS } \\
\hline & & 1 & $\%$ & 2 & $\%$ & 3 & $\%$ & 4 & $\%$ & 5 & $\%$ \\
\hline $\mathrm{KmP8}$ & $\begin{array}{l}\text { Pegawai bersedia } \\
\text { bekerja seoptimal } \\
\text { mungkin untuk } \\
\text { tercapainya tujuan } \\
\text { perusahaan. }\end{array}$ & 0 & 0,00 & 0 & 0,00 & 8 & 8,25 & 59 & 60,82 & 30 & 30,93 \\
\hline & Rata-rata & & $\mathbf{0 , 0 0}$ & & 1,29 & & 8,76 & & 61,60 & & 28,35 \\
\hline
\end{tabular}

Sumber: Data Primer Diolah, 2019

Berdasarkan Tabel 8. Dari variabel Komitmen pegawai mayoritas responden menjawab pertanyaan Setuju sebesar $57,35 \%$ sedangkan yang menjawab tidak setuju dari pertanyaan kuesioner pada variabel komitmen pegawai hanya sebesar 3,61\%. Komitmen merupakan sikap seseorang dalam mengidentifikasikan dirinya terhadap organisasi beserta nilai-nilai dan tujuannya, serta keinginan tetap menjadi anggota untuk mencapai tujuan. Jika karyawan merasa bahwa sikap dan nilai yang dianutnya sejalan dengan nilai-nilai yang ditetapkan dalam organisasi maka akan mendorong karyawan untuk mencapai tujuan organisasi, hal ini penting dalam upaya meningkatkan kinerja. Penelitian yang dilakukan oleh(Smith, 1996) menyatakan bahwa komitmen berpengaruh terhadap outcomes (keberhasilan) organisasi.

Tabel 9.

Rangkuman Persepsi Responden terhadap Variabel Kinerja Pegawai

\begin{tabular}{|c|c|c|c|c|c|c|c|c|c|c|c|}
\hline \multirow{2}{*}{\multicolumn{2}{|c|}{ ITEM PERTANYAAN }} & \multicolumn{2}{|c|}{ STS } & \multicolumn{2}{|c|}{ TS } & \multicolumn{2}{|c|}{$\mathbf{N}$} & \multicolumn{2}{|c|}{$\mathbf{S}$} & \multicolumn{2}{|r|}{ SS } \\
\hline & & 1 & $\%$ & 2 & $\%$ & 3 & $\%$ & 4 & $\%$ & 5 & $\%$ \\
\hline KP1 & $\begin{array}{l}\text { Pegawai selalu mengerjakan } \\
\text { pekerjaan dengan teliti. }\end{array}$ & 0 & 0,00 & 2 & 2,06 & 10 & 10,31 & 63 & 64,95 & 22 & 22,68 \\
\hline KP2 & $\begin{array}{l}\text { Pegawai sangat disiplin } \\
\text { dalam bekerja. }\end{array}$ & 0 & 0,00 & 0 & 0,00 & 4 & 4,12 & 67 & 69,07 & 26 & 26,80 \\
\hline KP3 & $\begin{array}{lr}\text { Pegawai } & \text { mampu } \\
\text { mengerjakan } & \text { pekerjaan } \\
\text { sesuai target } & \text { yang } \\
\text { ditentukan. } & \end{array}$ & 0 & 0,00 & 0 & 0,00 & 2 & 2,06 & 55 & 56,70 & 40 & 41,24 \\
\hline KP4 & $\begin{array}{l}\text { Pegawai selalu } \\
\text { menyelesaikan pekerjaan } \\
\text { dengan tepat waktu. }\end{array}$ & 0 & 0,00 & 0 & 0,00 & 2 & 2,06 & 41 & 42,27 & 54 & 55,67 \\
\hline
\end{tabular}

Bersambung... 
Lanjutan Tabel 9.

\begin{tabular}{|c|c|c|c|c|c|c|c|c|c|c|c|}
\hline \multirow{2}{*}{\multicolumn{2}{|c|}{ ITEM PERTANYAAN }} & \multicolumn{2}{|c|}{ STS } & \multicolumn{2}{|c|}{ TS } & \multicolumn{2}{|c|}{$\mathbf{N}$} & \multicolumn{2}{|c|}{$\mathbf{S}$} & \multicolumn{2}{|r|}{ SS } \\
\hline & & 1 & $\%$ & 2 & $\%$ & 3 & $\%$ & 4 & $\%$ & 5 & $\%$ \\
\hline KP5 & $\begin{array}{l}\text { Waktu yang diberikan untuk } \\
\text { menyelesaikan pekerjaan } \\
\text { telah sesuai dengan } \\
\text { kemampuan pegawai. }\end{array}$ & 0 & 0,00 & 0 & 0,00 & 4 & 4,12 & 55 & 56,70 & 38 & 39,18 \\
\hline KP6 & $\begin{array}{l}\text { Pegawai selalu masuk dan } \\
\text { pulang kerja tepat waktu. }\end{array}$ & 0 & 0,00 & 4 & 4,12 & 12 & 12,37 & 56 & 57,73 & 25 & 25,77 \\
\hline KP7 & $\begin{array}{l}\text { Pegawai melaksanakan } \\
\text { pekerjaan dengan penuh } \\
\text { tanggung jawab. }\end{array}$ & 0 & 0,00 & 0 & 0,00 & 8 & 8,25 & 59 & 60,82 & 30 & 30,93 \\
\hline
\end{tabular}

Sumber: Data Primer Diolah, 2019

Berdasarkan Tabel 9. Dari variabel kinerja pegawai mayoritas responden menjawab pertanyaan Setuju sebesar 58,32\% sedangkan yang menjawab tidak setuju dari pertanyaan kuesioner pada variabel kinerja pegawai hanya sebesar $0,88 \%$. Sehubungan dengan ukuran penilaian prestasi kerja maka kinerja pegawai, menurut (Robbins and Stephen D, 2000), faktor-faktor yang mempengaruhi kinerja adalah kuantitas hasil kerja, yaitu jumlah produksi kegiatan yang dihasilkan atau diselesaikan. Pengukuran kuantitatif melibatkan perhitungan keluaran dari proses atau pelaksanaan kegiatan. Ini berkaitan dengan jumlah keluaran yang dihasilkan. Kuantitas hasil kerja dapat dilihat dari prestasi kerja yang dicapai karyawan dan pencapaian target pekerjaan karyawan.Kualitas hasil kerja, yaitu mutu yang harus dihasilkan (baik tidaknya). Pengukuran kualitatif keluaran mencerminkan pengukuran "tingkat kepuasan",yaitu seberapa baik penyelesaiannya. Ini berkaitan dengan bentuk keluaran seperti keterampilan, kepuasan pelanggan, ataupun inisiatif.Ketepatan waktu, yaitu sesuai tidaknya dengan waktu yang direncanakan. Pengukuran ketepatan waktu merupakan jenis khusus dari pengukuran kuantitatif yang menentukan ketepatan waktu penyelesaian suatu kegiatan. Hal ini dapat kita lihat dari tingkat kehadiran karyawan, ketaatan karyawan dalam bekerja.

Analisis selanjutnya adalah analisis Partial Least Square (PLS) secara full model (tanpa melibatkan indikator yang tidak valid). Berikut pada Gambar 2. adalah hasil PLS.

Berdasarkan Gambar 2. Uji CFA_2 Eksogen dan Endogen, Pada Konstruk Endogen pada variabel Komitmen Pegawai (Y1) dan Kinerja Pegawai (Y2) sudah tidakterdapat nilai muatan faktor loading $<0,5$. Sehingga semua indikator pada Konstruk eksogen Pada Variabel Pengawasandan Motivasi serta Konstruk Endogen pada Variabel Komitmen Pegawai dan Kinerja Pegawai sudah menunjukkan valid.Hasil perhitungan reliabilitas dengan Composite Reliability dari Analisis Faktor Konfirmatori / CFA variabel eksogen dam Endogen juga 
menunjukkan seluruh varibelpenelitian dalam full model memiliki reliabilitas yang baik.

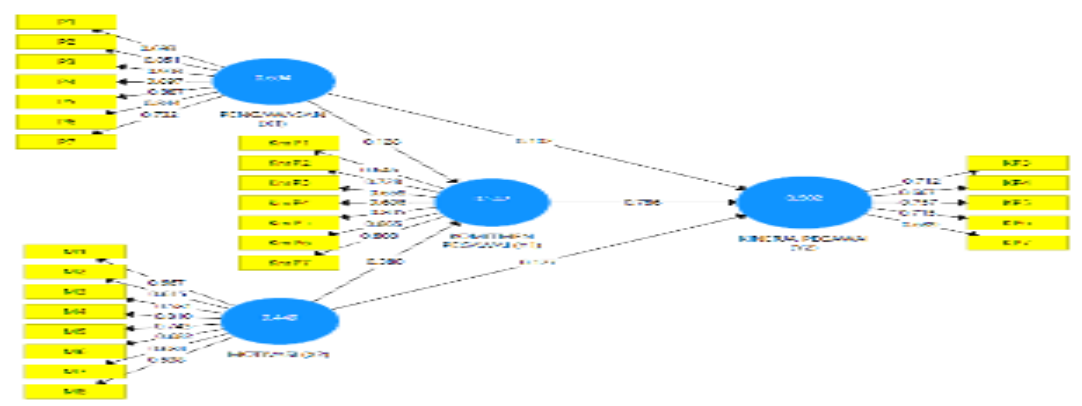

Gambar 2. Model Hasil PLS

Tabel 10.

Nilai koefisien dan t-hitung pada taraf $5 \%$

\begin{tabular}{lllll}
\hline Variabel & Koefisien & $\begin{array}{l}\text { t-hitung } \\
(\mathbf{1}, \mathbf{9 6} \mid)\end{array}$ & P Values & Keterangan \\
\hline Komitmen Pegawai ->Kinerja & 0,786 & 16,565 & 0,000 & Signifikan \\
Pegawai & 0,380 & 4,117 & 0,000 & Signifikan \\
Motivasi ->Komitmen Pegawai & 0,127 & 4,272 & 0,000 & Signifikan \\
Motivasi ->Kinerja Pegawai & 0,128 & 1,687 & 0,095 & Tidak Signifikan \\
Pengawasan ->Komitmen & 2,414 & 0,018 & Signifikan \\
Pegawai & & & \\
Pengawasan ->Kinerja Pegawai & 0,102 & &
\end{tabular}

Sumber: Hasil Olah Data Penelitian (2019)

Berdasarkan Tabel 10. di atas, maka diperoleh persamaan sebagai berikut: Komitmen Pegawai $=0.128 *$ Pengawasan $+0.380 *$ Motivasi

Berdasarkan model sub struktural dapat dijelaskan bahwa Komitmen Pegawai dipengaruhi secara langsung oleh Pengawasan $\left(\mathrm{X}_{1}\right)$ Dan Motivasi $\left(\mathrm{X}_{2}\right)$. Hal ini menunjukan bahwa Pengawasan berpengaruh positif terhadap Komitmen Pegawai sebesar 1,128 dan Motivasi berpengaruh positif sebesar 0.380 terhadap Komitmen Pegawai-Pegawai Rumah Sakit Umum Muaradua OKU Selatan.

Kinerja Pegawai $=0,786 *$ Komitmen Pegawai $0.102 *$ Pengawasan + $0.127 *$ Motivasi

Berdasarkan model struktural di atas dapat dijelaskan bahwa Kinerja Pegawai dipengaruhi secara langsung oleh Pengawasan $\left(\mathrm{X}_{1}\right)$, Motivasi $\left(\mathrm{X}_{2}\right)$ danKomitmen Pegawai $\left(\mathrm{Y}_{1}\right)$. Besarnya pengaruh Pengawasan terhadap Kinerja Pegawai sebesar 0,102, Motivasi terhadap Kinerja Pegawai sebesar 0,127, dan Komitmen Pegawai terhadap Kinerja Pegawai sebesar 0,786. Artinya Komitmen Pegawai mempunyai pengaruh yang lebih besar terhadap Kinerja Pegawai daripada Pengawasan dan Motivasi pada Pegawai Rumah Sakit Umum Muaradua OKUSelatan.

Hasil Pengujian Pengaruh Langsung dan Pengaruh Tidak Langsung. 
Tabel 11.

Pengaruh Langsung dan Tidak Langsung

\begin{tabular}{llllll}
\hline $\begin{array}{l}\text { Variabel } \\
\text { Bebas }\end{array}$ & $-->$ & $\begin{array}{l}\text { Variabel } \\
\text { Terikat }\end{array}$ & $\begin{array}{l}\text { Pengaruh } \\
\text { Langsung }\end{array}$ & $\begin{array}{l}\text { Pengaruh Tidak } \\
\text { Langsung }\end{array}$ & $\begin{array}{l}\text { Efek } \\
\text { Total }\end{array}$ \\
\hline Pengawasan & $-->$ & Kinerja & 0,102 & 0,100 & 0,202 \\
Motivasi & $-->$ & Pegawai & 0,127 & 0,298 & 0,426 \\
\hline Sumber: Hasil Olah Data Penelitian, 2019 & & &
\end{tabular}

Berdasarkan Tabel 11.menunjukkan bahwa nilai koefisien pengaruh langsung Pengawasan terhadap Kinerja Pegawai(0,102), pengaruh tidak langsung $(0,100)$ dan efek total $(0,202)$. Nilai koefisien pengaruh langsung Motivasi terhadap Kinerja Pegawai $(0,127)$, pengaruh tidak langsung $(0,298)$ dan efek total $(0,426)$. Hal tersebut berarti Pengawasan dan Motivasi berpengaruh terhadap Kinerja Pegawai-Pegawai dengan Komitmen Pegawai sebagai variabel intervening.

Pengaruh Pengawasanterhadap Komitmen Pegawai. Pengujian Hipotesis menunjukan variabel Pengawasan tidak berpengaruh sebesar 1,687 $(<1,96)$ terhadap Komitmen Pegawai-Pegawai Rumah Sakit Umum Muaradua OKUSelatan.Dengan demikian Hipotesis 1 tidak diterima.

Sesuai dengan pendapat (Effendi, 2014)mengatakan pengawasan sama dengan pengendalian sebagai proses memantau kegiatan-kegiatan untuk memastikan bahwa kegiatan-kegiatan itu diselesaikan sebagaimana telah direncanakan dan proses mengoreksi setiap penyimpangan yang berarti .

Pada penelitian ini pengawasan tidak berpengaruh terhadap komitmen pegawai. Penelitian ini sama dengan hasil penelitian yang di lakukan oleh (Neves, 2011) dan (Vandenberghe \& Bentein, 2004) yaitu pengawasan dan kompetensi tidak nilai negative atau tidak berpengaruh langsungterhadap komitmen pegawai. Karena pengawasan dan kompetensi masih kurang dan tidak memiliki sistem kenaikan karir sehingga membuat pegawai tidak memiliki motivasi kerja.

Pengaruh Motivasi terhadap Komitmen Pegawai. Pengujian Hipotesis menunjukan variabel Motivasi berpengaruh signifikan sebesar 4,117 $(>1,96)$ terhadap Komitmen Pegawai Pegawai Rumah Sakit Umum Muaradua OKUSelatan, dengan demikian Hipotesis 2 di terima.

Membuktikan Hasil Penelitian (Thacker, 1992) dalam (Husnawati, 2006) yang menunjukkanbahwa suksesnya implementasi program motivasi kerja secara keseluruhanberdampak positif terhadap komitmen pegawai. Sementara penelitian (Zin, 2004) dan (Husnawati, 2006) menunjukkan bahwa untuk meningkatkan komitmen pegawai perusahaan harus mengembangkan suatu motivasi kerja dengan memberikan kesempatan bagi pegawai untuk mengembangkan diri melalui program pelatihan dan berpartisipasi dalam setiap pengambilan keputusan yang berhubungan dengan pekerjaan mereka.

Pengaruh Pengawasan terhadap Kinerja Pegawai. Pengujian Hipotesis menunjukan variabel Pengawasan berpengaruh signifikan sebesar 2,414 $(>1,96)$ terhadap Kinerja Pegawai Rumah Sakit Umum Muaradua OKUSelatan. Dengan demikian Hipotesis 3 diterim Menurut (Husaini, 2009) yang mengatakan bahwa pengawasan pada dasarnya menekankan langkah-langkah pembenahan atau koreksi yang objektif jika terjadi perbedaan atau penyimpangan antara 
pelakasanaan dengan perencanaannya sehingga tidak memberi pengaruh buruk terhadap kinerja Pegawai. Dalam makna ini pengawasan juga berarti mengarahkan atau mengkoordinasikan antar kegiatan agar pemborosan sumber daya dapat dihindari.

Pengaruh Motivasi terhadap KinerjaPegawai .Pengujian Hipotesis menunjukan variabel Motivasi berpengaruh signifikan sebesar 4,272 (>1,96) terhadap kinerja pegawai Rumah Sakit Umum Muaradua OKUSelatan. Dengan demikian Hipotesis 4 diterima.

Mendukung penelitian (Hanafi et al., 2015) yang menyatakan adanya hubungan positif dan signifikan variabel motivasi kerja terhadap kinerja pegawai. Motivasi menjadi penting karena dengan motivasi diharapan setiap pegawai mau bekerja keras dan antusias untuk mencapai kinerja yang maksimal. Organisasi menaruh harapan yang besar kepada pegawai untuk mendapatkanhasil kerja yang memuaskan, sehingga target terealisasi.

Pengaruh Komitmen Pegawai terhadap Kinerja Pegawai. Pengujian Hipotesis menunjukan variabel Komitmen Pegawai berpengaruh signifikan sebesar 16,565 $(>1,96)$ terhadap kinerja pegawai Rumah Sakit Umum Muaradua OKUSelatan. Dengan demikian Hipotesis 5 diterima.

Penelitian ini mendukung Penelitian yang dilakukan oleh Smith (1996) menyatakan bahwa komitmen berpengaruh terhadap outcomes (keberhasilan) organisasi. Penelitian yang dilakukan oleh (Mowday et al., 1983) membuktikan adanya pengaruh yang positif dan signifikan dari komitmen organisasi dengan kinerja pegawai.

Pengaruh Pengawasan terhadap kinerja pegawai melalui komitmenPegawai. Pengujian Hipotesis menunjukan variabel pegawasan berpengaruh sebesar 0,100 terhadap kinerja pegawai melalui komitmen pegawai sebagai variabel intervening pada Rumah Sakit Umum Muaradua OKUSelatan. Dengan demikian Hipotesis 6 diterima

Penelitian ini juga sesuai dengan teori yang dikemukakan oleh (Mangkunegara A. A., 2009) yang menjelaskan bahwa pengawasan mempunyai peran penting untuk mengawasi standar pelaksanaan guna mencapai tujuan tujuan perencanaan, membandingkan kegiatan nyata dengan standar yang telah ditetapkan sebelumnya, menemukan dan mengukur penyimpangan untuk menjamin bahwa semua sumber daya perusahaan dipergunakan dengan cara efektif dan efisien dalam mencapai tujuan perusahaan.

Pengaruh Motivasi terhadap kinerja pegawai melalui komitmen Pegawai. Pengujian Hipotesis menunjukan variabel Motivasi berpengaruh sebesar 0,298 terhadap kinerja pegawai melalui komitmen pegawai sebagai variabel intervening padaRumah Sakit Umum Muaradua OKUSelatan. Dengan demikian hipotesis 7 diterima.

Pelitian ini juga sesuai dengana teori yang di kemukakan oleh (McClelland, 1983) yang menjelaskan tentang keinginan seseorang untuk mencapai kinerja yang tinggi. Hasil penelitian tentang motivasi berprestasi menunjukkan pentingnya menetapkan target atau standar keberhasilan. Karyawan dengan ciriciri motivasi berprestasi yang tinggi akan memiliki keinginan bekerja yang tinggi. 
Penerapan penelitian ini dalam segi teori, menambah pengetahuan tentang Pengawasan, Motivasi, Kinerja Pegawai, dan Komitmen Pegawai bagi peneliti selanjutnya. Menambah teori tersebut dalam aspek kehidupan berorganisasi, sebab teori tanpa adanya implikasi, maka tidak akan ada hasil. Teori dan praktek berkesinambungan, pada dasarnya semua saling terikat satu sama lain. Maka dari itu semoga penelitian ini bermanfaat bagi sesama peneliti maupun peneliti yang akan meneliti dibidang yang sama. Temuan penelitian ini mendukung pemikiran dari beberapa penelitian terdahulu penelitian yang dilakukan oleh (Amanda, 2016), menyimpulkan bahwa adanya pengaruh positif dan signifikan antara pengawasan dan disiplin kerja terhadap kinerja karyawan. Pengawasan berpengaruh positif terhadap disiplin kerja. Berdasarkan perhitungan dari penelitian ini disiplin kerja merupakan variabel intervening atau memediasi pengaruh antara pengawasan terhadap kinerja karyawan. Penelitian yang dilakukan oleh (Alfahri \& Iqbal, 2015), menyimpulkan bahwa hasil penelitian menunjukkan faktor higienis dan faktor motivator berpengaruh terhadap komitmen pegawai melalui kepuasan kerja, sehingga dapat disimpulkan bahwa motivasi kerja yang tinggi akan mempengaruhi peningkatan kepuasan kerja, ketika kepuasan kerja tinggi maka kepuasan kerja menjadi pengaruh tidak langsung antara kepuasan dan komitmen pegawai.

Penelitian ini tidak terlepas dari keterbatasan dan kelemahan. Keterbatasan dan kelemahan yang ditemukan dalam penelitian ini dapat digunakan sebagai sumber ide bagi penelitian yang akan datang. Adapun keterbatasan yang ditemukan dalam penelitian ini adalah penelitian ini hanya mengambil objek penelitian pada Rumah Sakit Umum Daerah Muaradua Kabupaten Ogan Komering Ulu Selatan sehingga memiliki keterbatasan untuk generalisasi hasil penelitian. Penelitian mungkin akan memberikan hasil yang berbeda jika dilakukan pada instansi lain.

Penelitian mendatang sebaiknya dilakukan pada objek penelitian yang lebih luas lagi, dan menambah variabel yang belum termasuk dalam penelitian ini seperti variabel kompetensi.

\section{SIMPULAN}

Berdasarkan hasil penelitian yang telah diuraikan pada bab sebelumnya dapat ditarik kesimpulan menyatakan hasil penelitian mendukung hipotesis $1\left(\mathrm{H}_{1}\right)$ yang menyatakan bahwa Pengawasan tidak berpengaruh terhadap Komitmen Pegawai. Hasil penelitian mendukung hipotesis $2\left(\mathrm{H}_{2}\right)$ yang menyatakanbahwaMotivasi berpengaruh terhadap Komitmen Pegawai.Hasil penelitian mendukung hipotesis $3\left(\mathrm{H}_{3}\right)$ yang menyatakan bahwa Pengawasan berpengaruh terhadap Kinerja Pegawai.Hasil penelitian mendukung hipotesis 4 $\left(\mathrm{H}_{4}\right)$ yang menyatakan Motivasi berpengaruh terhadap Kinerja Pegawai.Hasil penelitian mendukung hipotesis $5\left(\mathrm{H}_{5}\right)$ yang menyatakan bahwa Komitmen Pegawai berpengaruh terhadap Kinerja Pegawai.Hasil penelitian mendukung hipotesis $6\left(\mathrm{H}_{6}\right)$ yang menyatakan adapengaruh Pengawasan terhadap kinerja pegawai melalui komitmen pegawai.Hasil penelitian mendukung hipotesis $7\left(\mathrm{H}_{7}\right)$ yang menyatakan ada pengaruh Motivasi terhadap kinerja pegawai melalui komitmen pegawai. 
Berdasarkan analisis dan hasilyang ditemukan dalam penelitian ini, maka dapat diberikan saran Pihak Manajerial Rumah Sakit Mauaradua sebaiknya melakukan perubahan, pengembangan dan perbaikan dalam prosedur pelaksanaan kerja sehingga pekerjaan administrasi perkantoran berjalan lebih baik. Pihak manajemen perlu menjelaskan pentingnya pengawasan dan motivasi, di mana atasan dapat memberikan masukan dan perbaikan kepada pegawai dalam mengerjakan pekerjaan sehingga dapat mencapai hasil kinerja yang diharapkan dan diperlukan bagi karyawan itu sendiri, untuk meningkatkan keterampilannya di dalam bekerja, baik itu secara individu maupun kelompok.Pihak manajerial Rumah Sakit Muaradua harus lebih memperhatikan lebih terhadap segala aspek yang berpengaruh terhadap pola motivasi kerja karyawan kesetabilan kerja terus berlanjut. Untuk meningkatkan Komitmen pegawai dalam bekerjapada Rumah Sakit Muaradua,maka motivasi karyawan perlu di tingkatkan, sehingga dengan meningkatnya motivasi kerja karyawan dapat menimbulkan karyawan untuk berkomitmen bekerja lebih giat dan rajin lagi.

\section{REFERENSI}

Alfahri, \& Iqbal, M. (2015). Pengaruh Kelengkapan Sumber Belajar dan Kemandirian Belajar Terhadap Prestasi Belajar Siswa Pada Mata Pelajaran Ekonomi Kelas X SMA NEGERI 1 Binjai Tahun Pelajaran 2014/2015.

Allen, J. N. and M. J. P. (2001). The Measurement and Antecedents Of Affective, Continuance and Normative Commitment To The Organization. Great Britian: Journall of Occupational Psychology.

Amanda, R. (2016). Pengaruh Pengawasan Terhadap Kinerja Karyawan Melalui Disiplin Kerja Sebagai Variabel Intervening di PT Astra International Tbk Waru pada Bagian Part \& Accesories (Depo), 4, 1-8.

Effendi, U. (2014). Asas Manajemen. Jakarta: Rajawali Pers.

Ferdinand, A. (2014). Metode Penelitian Manajemen. Semarang: BP Universitas Diponogoro.

Ghozali, I. (2006). Aplikasi Analisis Multivariate dengan Program SPSS (4th ed.). Semarang: Universitas Diponegoro.

Gibson, James L, J. M. D. J. (2007). Organisasi (Delapan). Jakarta: Binarupa Alasara.

Gillis, D, A. (1994). Manajemen Keperawatan: Suatu Pendekatan Sistem. (Philadelphia, Ed.) (3rd ed.). W.B Sauder Company.

Hanafi, Agustina \& Destikarini, F. (2015). Analisis Pengaruh Kepuasan Kerja Dan Motivasi Kerja Organisasional Sebagai Variabel Intervening.

Harahap, S. (2011). Teori Akuntansi. Jakarta: Rajawali Pers. 
Harsan, E. (2011). Filsafat Ilmu dan Metodologi Penelitian Ilmu Pemerintahan. Bandung: Galia Indonesia.

Husaini, U. (2009). Metodologi Penelitian Sosial. Jakarta: Bumi Aksara.

Husnawati, A. R. I. (2006). Analisis Pengaruh Kualitas Kehidupan Kerja Terhadap Kinerja Karyawan Dengan Komitmen Dan Kepuasan Kerja Sebagai Intervening Variabel.

Kreitner dan Knicki. (2010). Organizational Behavior. New York: Mc Grow-Hill.

Luthans, F. (2009). Prilaku Organisasi. (V. A Yuwono, Ed.) (Bahasa Ind). Yogyakarta.

Mangkunegara A. A. (2009). Manajemen Sumber Daya Manusia. Bandung: PT. Remaja Resdakarya.

Mathew, V. H. and A. (2002). Biochemistry (3rd ed.). San Fransisco: Benjamin Cummings.

Mathis. L. R. Dan Jackson. H. j. (2001). Manajemen Sumber Daya Manusia. Jakarta: Buku Kedua.

McClelland, D. . (1983). Human Motivation. New York: Acaademic Press.

Mowday, Steers, R \& Poter, L. W. (n.d.). Motivation and Work Behavior. New York: Acaademic Press.

Nawawi, H. (2005). Penelitian Terapan. Yogyakarta: Gajah Mada.

Neves, P. (2011). Building commitment to change: The role of perceived supervisor support and competence, (13 Juli 2011).

P, F. A. B., Paramita, P. D., \& Wulan, H. S. (2016). Pengaruh Pengembangan Karir Dan Komunikasi Terhadap Komitmen Karyawan Yang Berdampak Pada Produktivitas Kerja, 2(2).

Robbin SP dan Judge. (2002). Prilaku Organisasi. Jakarta: Salemba Empat.

Robbins and Stephen D. (2000). Human Resources Management Concept and Practice. Jakarta: PT. Preenhalindo.

Robbins and Stephen D. (2008). Prilaku Organisasi. Jakarta: Salemba Empat.

Siregar, S. (2014). Metode Penelitian Kuantitatif. Jakarta: Kencana.

Sugiyono. (2015). Metode Penelitian Kombinasi (Mix Methods). Bandung: Alfabeta.

Sugiyono. (2017). Metode Penelitian Kualitatif: Untuk Penelitian Yang Bersifat Eksploratif, Enterpretif, Interaktif, dan Konstruktif. Bandung: Alfabeta. 
E-Jurnal Manajemen, Vol. 8, No. 12, 2019 : 7239-7259

Suharnami, A. \&. (2013). Prosedur Penelitian: Suatu Pendekatan Praktik. Jakarta: Rineka Cipta.

Suharnomo \& Febriani, D. (2018). Pengaruh Pengawasan, Motivasi Kerja, Dan Komunikasi Interpersonal Terhadap Kinerja Karyawan Dengan Komitmen Organisasi Sebagai Variabel Intervening, 7, 1-12.

Vandenberghe, C., \& Bentein, K. (2004). Affective commitment to the organization, supervisor, and work group: Antecedents and outcomes, 8791(February).

Wilson, B. (2012). Manajemen Sumber Daya Manusia. Jakarta: Erlangga.

Zin, R. M. (2004). Perception Of Professional Engineers Toward Quality Of Worklife And Organizational Commitment, 6(3). 